\title{
CSTB wt Allele
}

National Cancer Institute

\section{Source}

National Cancer Institute. CSTB wt Allele. NCI Thesaurus. Code C128871.

Human CSTB wild-type allele is located in the vicinity of $21 \mathrm{q} 22.3$ and is approximately 4 $\mathrm{kb}$ in length. This allele, which encodes cystatin-B protein, plays a role in thiol protease inhibition. Mutation of the gene is associated with progressive myoclonic epilepsy $1 \mathrm{~A}$ (myoclonic epilepsy of Unverricht and Lundborg). 